\title{
Bacterial abundance and production and heterotrophic nanoflagellate abundance in subarctic coastal waters (Western North Pacific Ocean)
}

\author{
Choon Weng Lee*, Isao Kudo, Mitsuru Yanada, Yoshiaki Maita \\ Laboratory of Marine Environmental Science, Graduate School of Fisheries Science, Hokkaido University, \\ 3-1-1 Minato, Hakodate, 041-8611 Japan
}

\begin{abstract}
We studied the temporal variations of bacterial abundance and production in subarctic Funka Bay (Hokkaido, Japan) for a 1 yr period, and related this data to chlorophyll a (chl a) concentration (highest conc. $=5.9 \mathrm{\mu g} \mathrm{l}^{-1}$ ), particulate organic carbon (POC) concentration (ranging from 60 to $360 \mu \mathrm{g} \mathrm{C}^{-1}$ ), heterotrophic nanoflagellate (HNF) abundance $\left(<0.5\right.$ to $\left.5.6 \times 10^{3} \mathrm{cells} \mathrm{ml}^{-1}\right)$, and temperature. Bacterial abundance ranged from 2.6 to $9.1 \times 10^{5} \mathrm{cells} \mathrm{ml}^{-1}$, whereas bacterial production ranged from 0.1 to $22.9 \mu \mathrm{g} \mathrm{C} \mathrm{l}^{-1} \mathrm{~d}^{-1}$. The calculated bacterial growth rate ranged from 0.02 to $2.57 \mathrm{~d}^{-1}$, with an average turnover time of $1.6 \mathrm{~d}$, and 'attached' bacteria ( $>1 \mu \mathrm{m}$ fraction) contributed more than half the total bacterial production (mean $\pm 95 \% \mathrm{CL}=54 \pm 12 \%$ ). Bacterial abundance was relatively stable throughout the year (coefficient of variation, CV $=20 \%$ ) even though the CV for bacterial production was high $(\mathrm{CV}=100 \%)$. Grazing (top-down) is an important control mechanism in Funka Bay, and HNF seemed to be directly cropping bacterial production. Annual bacterial production was estimated at $140 \mathrm{~g} \mathrm{C} \mathrm{m}^{-2} \mathrm{yr}^{-1}$, and was relatively high compared to the annual primary production (100 to $170 \mathrm{~g} \mathrm{C} \mathrm{m}^{-2} \mathrm{yr}^{-1}$ ), indicating the importance of the microbial loop in Funka Bay. After bacterial respiration loss was accounted for, bacterial carbon demand was higher than primary production. The inflow of Tsugaru warm water, a branch of the Kuroshio Current brought organic matter, but the concentration of POC and the timing of the inflow suggested that this organic matter addition was insignificant, and we concluded that other sources, including riverine input, are more important sources of organic matter.
\end{abstract}

KEY WORDS: Bacterial production $\cdot$ Funka Bay $\cdot$ Heterotrophic nanoflagellate $\cdot$ Particulate organic matter · Tsugaru warm water

\section{INTRODUCTION}

Bacteria are responsible for much of the carbon and nutrient cycling in aquatic systems (e.g. Ducklow \& Carlson 1992, Simon et al. 1992). Bacteria act as an important link between detritus, dissolved organic matter and higher trophic organisms, especially heterotrophic nanoflagellates (HNF), which are the major consumers of bacteria (Sherr \& Sherr 1984). Currently,

*E-mail: lee@mespc4.fish.hokudai.ac.jp we know that substrate supply, grazing, temperature and viruses are the principal factors that control both bacterial abundance and production (Sherr \& Sherr 1984, Fuhrman \& Noble 1995, Felip et al. 1996). However, among these factors, the most critical one differs at different locations and at different periods of time (Shiah \& Ducklow 1994, Goosen et al. 1997, FerrierPagès \& Gattuso 1998).

This study aimed at determining the influence of bacteria on the carbon budget of Funka Bay. Funka Bay is located in the subarctic region, southwest of 
Hokkaido, Japan; it covers an area of about $2300 \mathrm{~km}^{2}$ and has a maximum depth of about $100 \mathrm{~m}$ (see Fig. 1). The ecology of both micro- and net-plankton have been well studied in this bay (Odate 1992), but the role played by bacteria has remained uncertain. This study had 2 goals: (1) to measure the bacterial production rates in this region for the first time, and (2) to address the potential mechanisms of control for bacterial abundance and production.

We investigated the temporal variations of both bacterial abundance and production in a $1 \mathrm{yr}$ study, and related this to both chlorophyll a concentration and HNF abundance. Since typically more than half the phytoplankton productivity is in the form of particulate (rather than dissolved) organic matter (Baines \& Pace 1991), attached bacteria may play a significant role in the breakdown of particulate matter. Although freeswimming bacteria (or bacterioplankton) may be able to graze on particulate substrates without becoming firmly attached (Kefford et al. 1982), it is generally assumed that detritus is degraded primarily by bacteria attached to the particulate material (Hoppe 1991). Our results indicated that more than half of the bacterial production could be attributed to 'attached' bacterial (>1 $\mu \mathrm{m}$ fraction) production. The estimated annual bacterial production was also high relative to annual primary production, suggesting the importance of the microbial loop in Funka Bay.

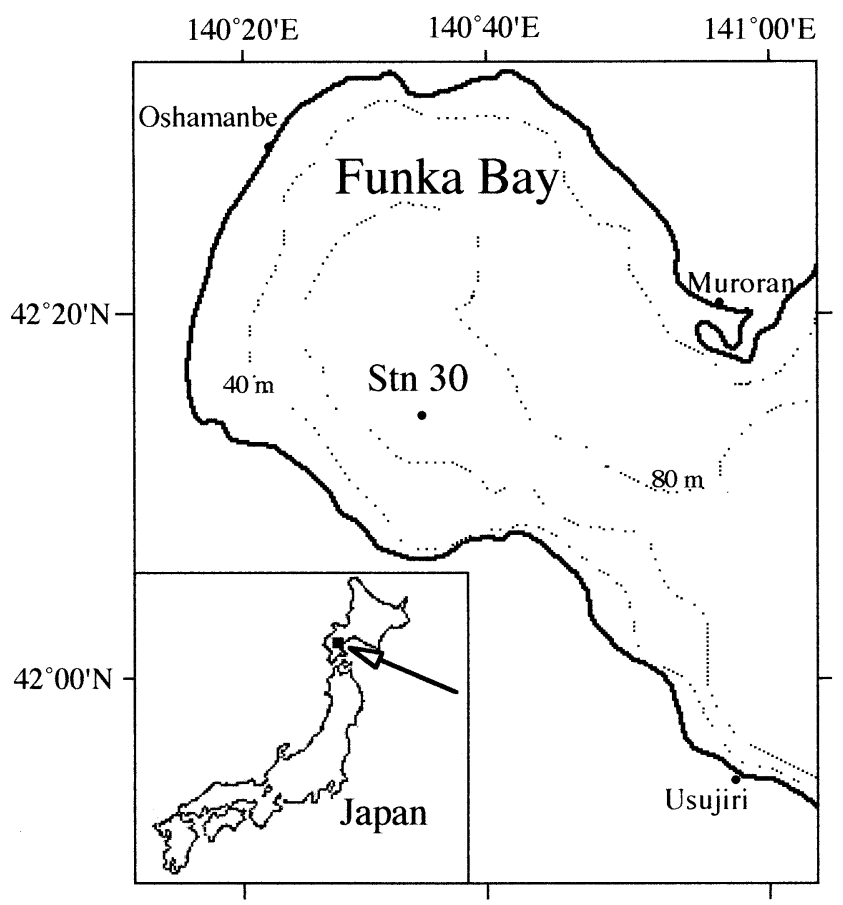

Fig. 1. Location of Sampling Stn $30\left(42^{\circ} 16.2^{\prime} \mathrm{N}, 140^{\circ} 36.0^{\prime} \mathrm{E}\right)$ in Funka Bay, south-western Hokkaido, Japan. Isobaths for 40 and $80 \mathrm{~m}$ depths are delineated by dotted lines. Inset: location of Funka Bay in Japan

\section{MATERIALS AND METHODS}

Sampling was carried out on 9 occasions at Stn 30 (average depth of $92 \mathrm{~m}$ ) in Funka Bay $\left(42^{\circ} 16.2^{\prime} \mathrm{N}\right.$, $140^{\circ} 36.0^{\prime} \mathrm{E}$ ) (Fig. 1) from February until December 1999. Seawater samples were collected at intervals of $10 \mathrm{~m}$ down to $90 \mathrm{~m}$ depth using $5 \mathrm{l}$ Niskin samplers; samples $30 \mathrm{~cm}$ above the bottom were collected with a devised water sampler. Subsamples for the determination of microbial abundance were preserved with filtered (Nuclepore filter, $0.2 \mu \mathrm{m}$ pore size) $1 \%$ glutaraldehyde (final conc.). The remaining samples were kept in a cooler box for no more than $5 \mathrm{~h}$ until processing in the laboratory. Pre-combusted $\left(450^{\circ} \mathrm{C}\right.$ for $5 \mathrm{~h}$ ) Whatman GF/F filters (nominal pore size $0.7 \mu \mathrm{m}$ ) were also used to collect samples for both chlorophyll $a$ (chl a) and particulate organic matter (POM) determinations, and were stored at $-30^{\circ} \mathrm{C}$ until analysis.

The temperature-salinity profile at the time of sampling was obtained with a CTD profiler (SeaBird SBE 19); photosynthetically active radiation (PAR) and light attenuation were measured with an underwater quantum sensor (LI-193SB, Li-Cor). The 1\% light-level depth ranged from 20 to $50 \mathrm{~m}$, average $( \pm 95 \%$ confidence limits $[C L])=32 \pm 8 \mathrm{~m}$. In this study, for analysis and discussion purposes, the euphotic layer was defined as the upper $30 \mathrm{~m}$ depth. Chl a was extracted with N, N-dimethylformamide (Suzuki \& Ishimaru 1990), and measured with a spectrofluorometer (F2000, Hitachi). For POM analysis, filters were dried for $5 \mathrm{~h}$ in a freeze-dryer (FDU-830, Eyela) and then analysed with an elemental analyser (CHN-Corder MT-5, Yanaco).

Bacterial abundance was determined by epifluorescence microscopy on samples stained with 4'6-diamidino-2-phenylindole (DAPI) $\left(0.1 \mu \mathrm{g} \mathrm{l}^{-1}\right.$ final conc.) for 7 min (Kepner \& Pratt 1994). More than 300 cells were counted for each sample. Some samples were duplicated $(\mathrm{n}=50)$, and the $\mathrm{CV}$ ranged from 2 to $21 \%$. Bacterial abundance was converted into biomass using the 'constrained' conversion factor of $15 \mathrm{fg} \mathrm{C}$ bacterium $^{-1}$ (Caron et al. 1995). For nanoflagellates, a $20 \mathrm{ml}$ sample was filtered onto a dyed $1.0 \mu \mathrm{m}$ pore size Nuclepore filter, and then stained with the fluorochrome primulin, and nanoflagellates without chl a fluorescence were counted as HNF (Bloem et al. 1986). About 50 cells were counted for each sample. Several samples were duplicated $(\mathrm{n}=12)$; $\mathrm{CV}$ ranged from 1 to $6 \%$.

Bacterial production was measured using the radiolabelled thymidine (TdR) incorporation method (Fuhrman \& Azam 1982). [Methyl- ${ }^{3} \mathrm{H}$ ]thymidine (final conc. $=$ $10 \mathrm{nM}$; specific activity 3.1 to $3.3 \mathrm{TBq} \mathrm{mmol}^{-1}$; New England Nuclear, USA) was added to triplicate $10 \mathrm{ml}$ samples. The CV ranged from 2 to $42 \%$; the average was $14 \%$. Samples were incubated for $1 \mathrm{~h}$ in the dark 
at the ambient temperature of the depth of collection $\left( \pm 2^{\circ} \mathrm{C}\right)$. Incubation was terminated by the addition of formaldehyde ( $10 \%$ final conc.). Bacteria were collected onto a $0.2 \mu \mathrm{m}$ Millipore filter, and washed 5 times with $2 \mathrm{ml}$ ice-cold $5 \%$ trichloroacetic acid. The filter was immediately placed into a vial filled with $8 \mathrm{ml}$ liquid scintillation solution and subsequently assayed for TdR incorporation. All samples were corrected for abiotic incorporation by subtracting the radioactivity in a formaldehyde-killed control. TdR incorporation rates were converted to bacterial production using a theo-

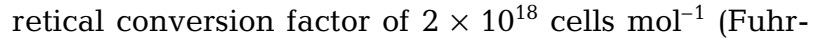
man \& Azam 1982).

In this study, we determined the contribution of attached bacteria indirectly by subtracting the bacterial production in the $<1 \mu \mathrm{m}$ fraction from the total. We defined operationally that the TdR incorporation in the $>1 \mu \mathrm{m}$ fraction was due to bacteria attached to larger particles. Samples were filtered using $1.0 \mu \mathrm{m}$ Nuclepore filters before incubating with TdR. The procedures for extraction and radioassay were as described above. The grazing potential of HNF was also estimated in August and December. The change in bacterial abundance for both the $<10$ and $<0.7 \mu \mathrm{m}$ fractions (10 and 90 m depth samples) was determined in a single $24 \mathrm{~h}$ culture, and the bacterial growth rate in each fraction was estimated. Bacterial activity was assumed the same for both the $<10$ and $<0.7 \mu \mathrm{m}$ fractions, and that bacteria grew exponentially during the incubation period ( $1 \mathrm{~d})$. HNF grazing potential was then estimated as the difference between bacterial growth rates in the $<0.7 \mu \mathrm{m}$ fraction (assumed free of grazing), and in the $<10 \mu \mathrm{m}$ fraction which presumably represented the product of both growth and grazing (McManus 1993).

All data are reported as means $\pm 95 \%$ confidence limits, and all other variables except for temperature were log-transformed to equalize variance (homoscedasticity) (Zar 1996). Bacterial growth rate (BGR) was calculated as bacterial production (BP) divided by abundance (BA), and error propagation analysis was carried out according to Day \& Underwood (1980) using the following equation:

$$
\left(\sigma_{\mathrm{BGR}}^{2} / \mathrm{BGR}\right)=\left(\sigma_{\mathrm{BP}}^{2} / \mathrm{BP}\right)+\left(\sigma_{\mathrm{BA}}^{2} / \mathrm{BA}\right)
$$

\section{RESULTS}

From temperature-salinity profiles, 2 external water masses were observed in Funka Bay, the Oyashio water after March, and the Tsugaru warm water (a branch of the Kuroshio Current) after August (Fig. 2). The Oyashio water is important to the timing of the spring bloom (Kudo \& Matsunaga 1999). Particulate organic carbon (POC) concentration ranged from 60 to $360 \mu \mathrm{g} \mathrm{C}^{-1}$ (Fig. 3A), particulate organic nitrogen

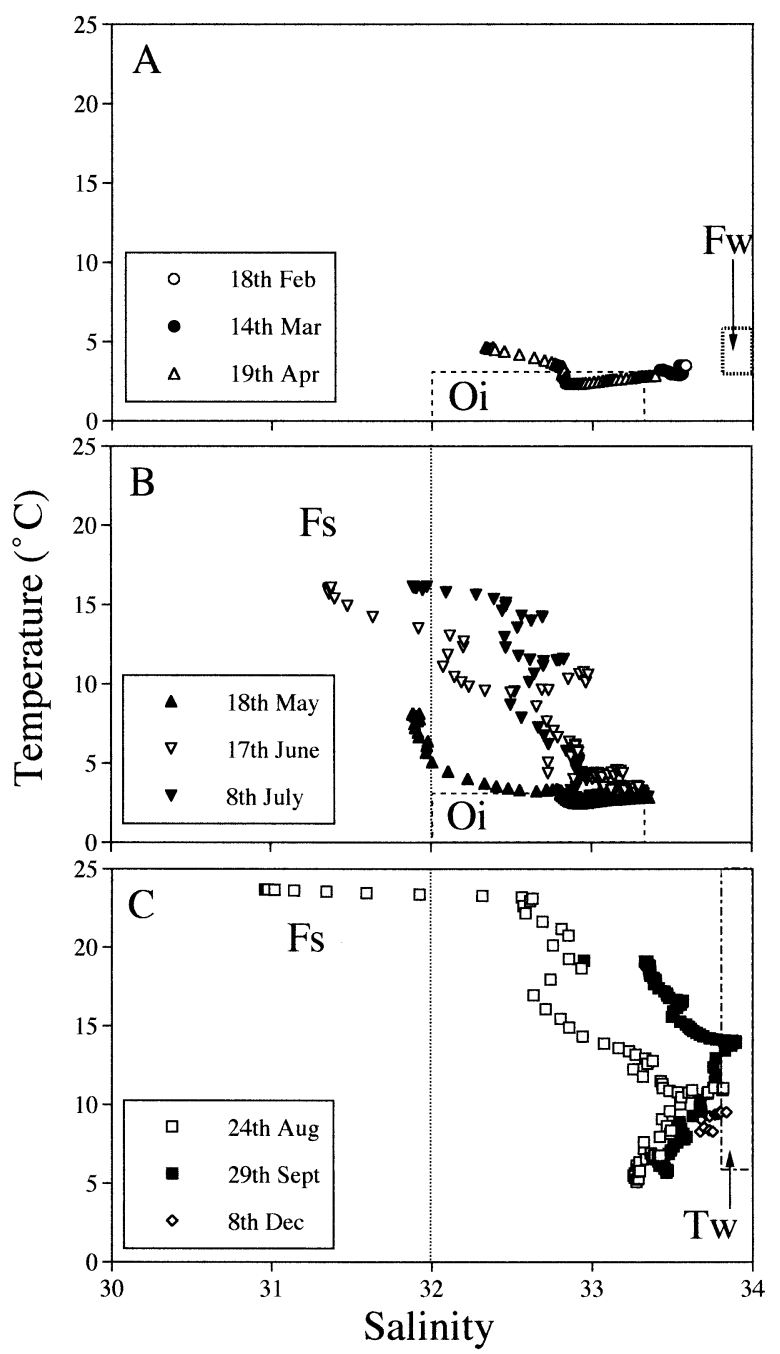

Fig. 2. Temperature-salinity profiles on each sampling occasion at Stn 30, Funka Bay. Temperature-salinity boundaries for the water masses are drawn according to Ohtani (1971). Fw: Funka Bay winter water (salinity >33.8, temperature $>3^{\circ} \mathrm{C}<6^{\circ} \mathrm{C}$ ); Fs: Funka Bay summer water (salinity <32); Oi: Oyashio water (salinity $>32.0<33.3$, temperature $<3^{\circ} \mathrm{C}$ ); Tw: Tsugaru warm water (salinity $>33.8$, temperature $>6^{\circ} \mathrm{C}$ )

(PON) concentration from 10 to $60 \mu g \mathrm{~N} \mathrm{l}^{-1}$ (Fig. 3B). The POC:PON ratio for the particulate organic matter ranged from 4 to 10 (Fig. 3C).

The chl a concentration, a common indicator of total phytoplankton was highest in March (10 m depth) at $5.9 \mathrm{\mu g} \mathrm{l}^{-1}$ (Fig. 4A). When the spring phytoplankton bloom period (March and April data) was excluded, the mean chl a concentration was $0.7 \pm 0.1 \mu \mathrm{g} \mathrm{l^{-1 }}$ (0 to $30 \mathrm{~m}$ layer), $0.5 \pm 0.2 \mathrm{\mu g}^{-1}$ (40 to $60 \mathrm{~m}$ layer), and $0.4 \pm$ $0.2 \mathrm{\mu g} \mathrm{l}^{-1}$ (70 to $90 \mathrm{~m}$ layer). In this study, bacterial abundance was higher in the euphotic layer, and especially in March and September $\left(>7 \times 10^{5}\right.$ cells $\left.\mathrm{ml}^{-1}\right)$ (Fig. 4B). Mean bacterial abundance in the 0 to $30 \mathrm{~m}$, 40 to $60 \mathrm{~m}$ and 70 to $90 \mathrm{~m}$ layers was $6.3 \pm 0.7 \times 10^{5}$, 

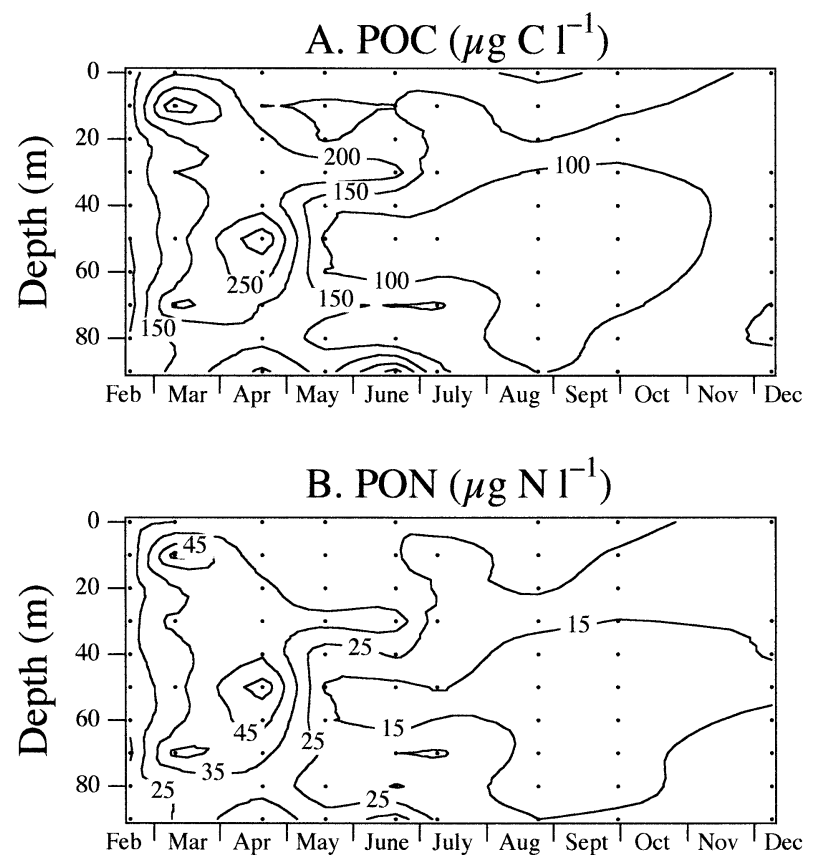

C. POC/PON

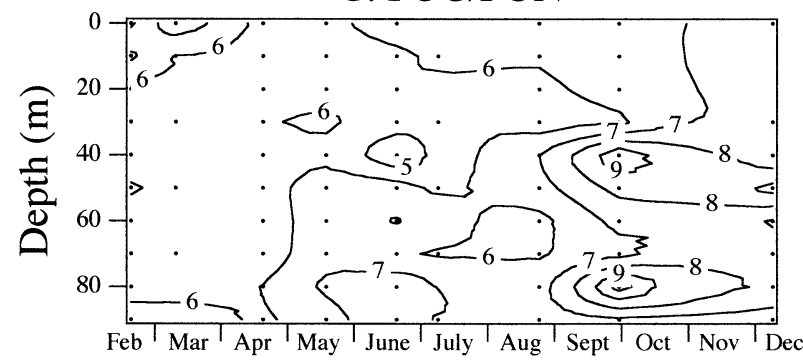

Fig. 3. Distribution of (A) particulate organic carbon (POC), (B) particulate organic nitrogen (PON) and (C) POC:PON ratio at Stn 30, Funka Bay

$4.9 \pm 0.5 \times 10^{5}$, and $4.8 \pm 0.3 \times 10^{5}$ cells $\mathrm{ml}^{-1}$, respectively. HNF abundance ranged from less than $0.5 \times 10^{3}$ to $5.6 \times 10^{3}$ cells ml $^{-1}$; the average was $1.6 \pm 0.3 \times 10^{3}$ cells $\mathrm{ml}^{-1}$ (Fig. 4C). HNF abundance decreased gradually throughout the water column towards winter.

In this study, the TdR incorporation rate ranged from 0.2 to $31.8 \mathrm{pM} \mathrm{h}^{-1}$ (Fig. 5), and bacterial production estimated from TdR incorporation ranged from 0.1 to $22.9 \mu \mathrm{g} \mathrm{C} \mathrm{l}^{-1} \mathrm{~d}^{-1}$. Bacterial production was higher in the euphotic layer, and was highest in March and lowest in December. Integrated bacterial production for the whole water column ranged from 0.04 to $0.79 \mathrm{~g} \mathrm{C} \mathrm{m}^{-2}$ $\mathrm{d}^{-1}$. Bacterial growth rate calculated ranged from 0.02 to $2.57 \mathrm{~d}^{-1}$; the average was $0.62 \pm 0.54 \mathrm{~d}^{-1}$. This meant that the mean turnover time or the reciprocal of growth rate for bacteria was $1.6 \mathrm{~d}$.

The production rate of attached bacteria was also estimated (Table 1); they contributed $54 \pm 12 \%$ to the

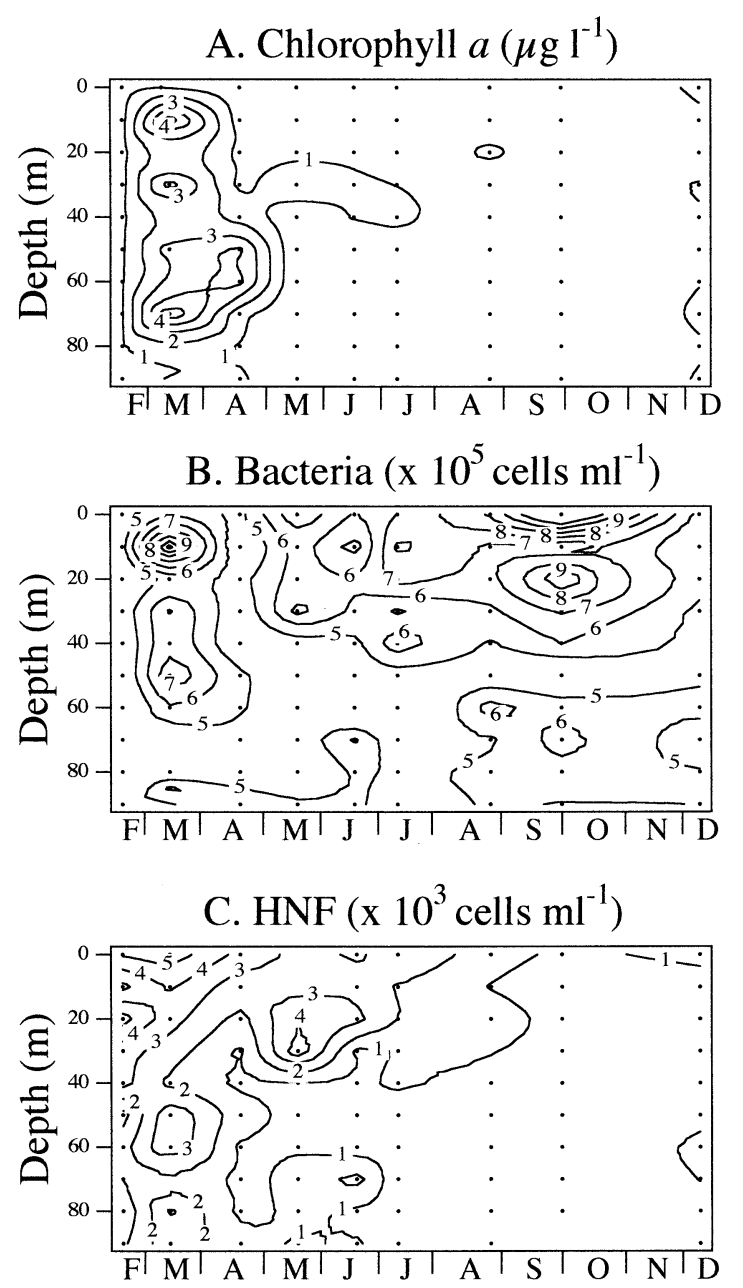

Fig. 4. Distribution of (A) chlorophyll $a$, (B) bacterial abundance, and (C) heterotrophic nanoflagellate (HNF) abundance at Stn 30, Funka Bay

total bacterial production. This is similar to the results of Kirchman \& Mitchell (1982), who found that in some aquatic systems more than $40 \%$ substrate incorporation rate could be attributed to attached bacteria. The percentage attached bacterial production contributed to total bacterial production ranged from 30 to 70,20 to 90 and 40 to $90 \%$ for the 10,50 and $90 \mathrm{~m}$ depth samples, respectively. The HNF potential grazing rate in August was 100 cells $\mathrm{HNF}^{-1} \mathrm{~h}^{-1}$ at $10 \mathrm{~m}$ depth and 16 cells $\mathrm{HNF}^{-1} \mathrm{~h}^{-1}$ at $90 \mathrm{~m}$ depth, whereas in December the grazing rate at $10 \mathrm{~m}$ was lower $\left(33\right.$ cells $\mathrm{HNF}^{-1} \mathrm{~h}^{-1}$ ) and was undetectable at $90 \mathrm{~m}$ depth (Table 2). The HNF potential grazing rates obtained in this study were within the range reported by Weisse \& ScheffelMöser (1991), who used the size-fractionation method. Quantitatively, the use of this potential grazing rate is doubtful, as uncertainty due to the assumptions made remains. However, the comparison of these rates in 
TdR Incorporation $\left(\mathrm{pM} \mathrm{h}^{-1}\right)$

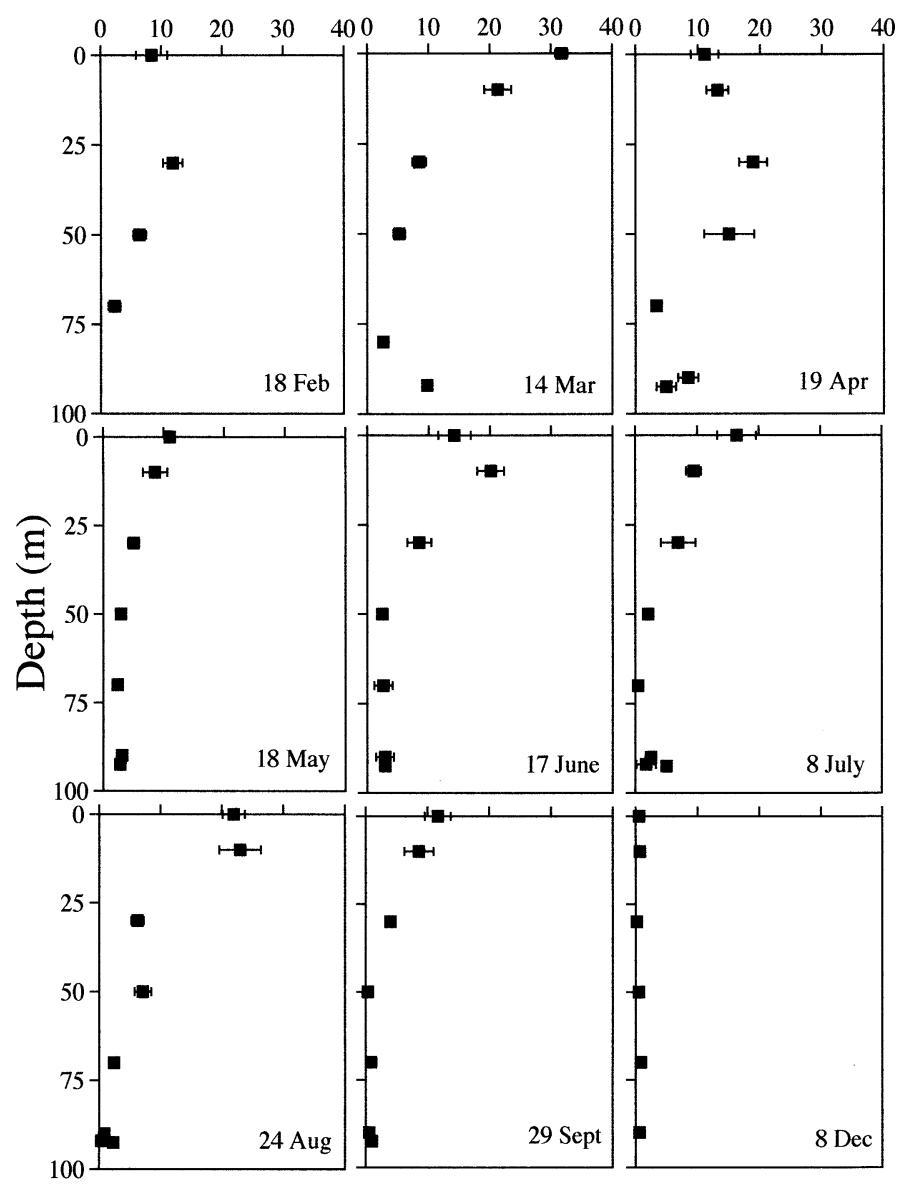

Fig. 5. Mean radio-labelled thymidine (TdR) incorporation rate at Stn 30, Funka Bay on each sampling occasion. Error bars $( \pm \mathrm{SD})$ are shown, except where they were smaller than the symbols

August and December did suggest how grazing could affect bacterial abundance. When HNF grazing rate was high (100 cells $\mathrm{HNF}^{-1} \mathrm{~h}^{-1}$ ), bacterial growth rate calculated from TdR incorporation method was also high $\left(1.6 \mathrm{~d}^{-1}\right)$.

\section{DISCUSSION}

In Funka Bay, the spring phytoplankton bloom occurs every March or April, and chl a concentration at its peak is usually above $10 \mu \mathrm{g}^{-1}$ (Odate 1992, Kudo \& Matsunaga 1999). In this study, the highest chl a concentration observed was $5.9 \mu \mathrm{g} \mathrm{l}^{-1}$, and the peak in spring phytoplankton bloom could have occurred between the March and April samplings. After the bloom, chl a concentration remained below $1.3 \mu \mathrm{g} \mathrm{l} \mathrm{l}^{-1}$ throughout the rest of the sampling period. The POC and PON concentrations in this study were similar to
Table 1. Contribution of attached bacteria to total bacterial production in Funka Bay. Attached bacterial production was calculated as the difference between the measured bacterial production in both the total and $<1 \mu \mathrm{m}$ fraction

\begin{tabular}{|c|c|c|c|}
\hline \multirow[t]{2}{*}{$\begin{array}{l}\text { Sample } \\
\text { depth (m) }\end{array}$} & \multicolumn{2}{|c|}{$\begin{array}{l}\text { Bacterial production } \\
\qquad\left(\mathrm{mg} \mathrm{C} \mathrm{m} \mathrm{m}^{-3} \mathrm{~d}^{-1}\right)\end{array}$} & \multirow{2}{*}{$\begin{array}{l}\% \text { attached bacterial } \\
\text { production contributed } \\
\text { to total } \\
\text { bacterial production }\end{array}$} \\
\hline & Total & $\begin{array}{c}\text { Attached } \\
\text { bacteria }\end{array}$ & \\
\hline \multicolumn{4}{|c|}{19 Apr 1999} \\
\hline 10 & 9.48 & 5.41 & 57.1 \\
\hline 90 & 6.06 & 4.65 & 76.7 \\
\hline \multicolumn{4}{|c|}{18 May 1999} \\
\hline 10 & 6.16 & 3.06 & 49.7 \\
\hline 50 & 2.08 & 0.48 & 23.1 \\
\hline \multicolumn{4}{|c|}{ 17 Jun 1999} \\
\hline 10 & 14.47 & 8.67 & 59.9 \\
\hline 50 & 1.74 & 0.61 & 35.1 \\
\hline 90 & 2.05 & 1.38 & 67.3 \\
\hline \multicolumn{4}{|l|}{8 Jul 1999} \\
\hline 10 & 6.79 & 1.08 & 15.9 \\
\hline 50 & 1.47 & 0.79 & 53.7 \\
\hline 90 & 1.81 & 0.68 & 37.6 \\
\hline \multicolumn{4}{|c|}{24 Aug 1999} \\
\hline 10 & 16.55 & 4.97 & 36.1 \\
\hline 50 & 5.11 & 4.34 & 84.9 \\
\hline 90 & 0.60 & 0.56 & 93.3 \\
\hline \multicolumn{4}{|c|}{29 Sep 1999} \\
\hline 10 & 6.19 & 1.59 & 25.7 \\
\hline \multicolumn{4}{|l|}{8 Dec 1999} \\
\hline 10 & 0.47 & 0.32 & 68.1 \\
\hline 50 & 0.37 & 0.32 & 86.5 \\
\hline 90 & 0.46 & 0.21 & 45.7 \\
\hline
\end{tabular}

those previously reported by Yanada \& Maita (1978). In the euphotic layer, integrated chl a was closely correlated with POC $(\mathrm{r}=0.87, \mathrm{n}=9, \mathrm{p}<0.01)$, and the POC concentration increase in March could be attributable to the increase in phytoplankton.

HNF abundance was within the range reported for various coastal areas (Fukami et al. 1996, Ferrier-Pagès \& Gattuso 1998), and both bacterial abundance and bacterial production were similar to the range detected in the open ocean in the subarctic Pacific (Simon et al. 1992), in the Ise Bay, Japan (Naganuma 1997), and the Seto Inland Sea, Japan (Naganuma \& Miura 1997). To discuss the possible mechanisms controlling bacterial abundance, we separated our data into 2 periods: (1) Early period, February until May, which covered both the spring bloom and post-spring bloom: there was a rapid change in chl a concentrations, and the monthly sampling strategy missed the peak in spring phytoplankton bloom; in view of this, sampling could at best provide 'snap shots' of the system at each date. (2) Late period, June until December, which covered the summer and early winter season: this period was relatively stable with respect to chl a concentrations, 
Table 2. Estimated heterotrophic nanoflagellate (HNF) potential grazing rate in August and December. nd: not detectable

\begin{tabular}{|lcccc|}
\hline $\begin{array}{l}\text { Depth } \\
(\mathrm{m})\end{array}$ & $\begin{array}{r}\text { Bacterial growth rate }\left(\mathrm{h}^{-1}\right) \\
<10 \mu \mathrm{m} \\
\text { fraction }\end{array}$ & $\begin{array}{c}<0.7 \mu \mathrm{m} \\
\text { fraction }\end{array}$ & $\begin{array}{c}\text { HNF abundance } \\
\text { in }<10 \mu \mathrm{m} \text { fraction } \\
\left(\times 10^{3} \text { cells } \mathrm{ml}^{-1}\right)\end{array}$ & $\begin{array}{c}\text { HNF potential } \\
\text { grazing rate } \\
\left(\text { cells HNF }^{-1} \mathrm{~h}^{-1}\right)\end{array}$ \\
\hline 24 Aug 1999 & & & & \\
10 & 0.029 & 0.055 & 0.30 & 100 \\
90 & 0.003 & 0.012 & 0.30 & 16 \\
8 Dec 1999 & & & 0.40 & 33 \\
10 & 0.023 & 0.059 & 0.30 & nd \\
90 & 0.019 & 0.013 & & \\
\hline
\end{tabular}

which remained at less than $1.3 \mu \mathrm{g}^{-1}$, and except for rare storm events that upwelled nutrients from below the thermocline, we were able to evaluate the whole period.

From large-scale comparisons, Cole et al. (1988) found that bacterial abundance correlated with $\mathrm{chl} a$
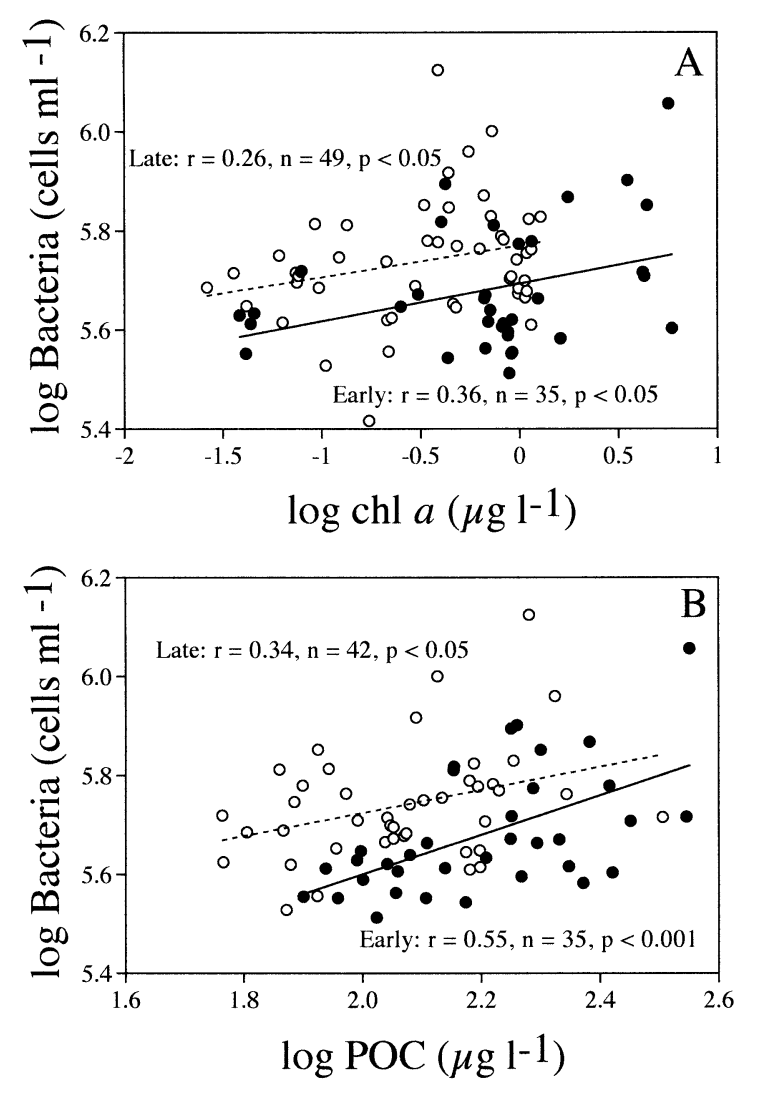

- Early period (Feb-May) o Late period (June-Dec)

Fig. 6. Correlation analyses for both early (spring bloom and post-spring bloom) and late (summer and early winter) periods for (A) log bacterial abundance and log chlorophyll a (chl a) concentration, and (B) log bacterial abundance and log particulate organic carbon (POC) concentration concentration, and concluded that in all aquatic systems bacterial production is sustained ultimately by organic matter from primary producers. Our results were consistent with this general model. In this study, bacterial abundance correlated with both chl a (Fig. 6A, early period: $\mathrm{r}=0.36, \mathrm{n}=35$, $\mathrm{p}<0.05$; late period: $\mathrm{r}=0.26, \mathrm{n}=49$, $\mathrm{p}<0.05)$ and POC concentrations for both periods (Fig. 6B, early period: $\mathrm{r}=0.55, \mathrm{n}=35, \mathrm{p}<0.001$; late period: $\mathrm{r}=0.34, \mathrm{n}=42, \mathrm{p}<0.05)$. The dependence of bacterial production upon POM was also reflected by the high percentage of total bacterial production contributed by the $>1 \mu \mathrm{m}$ fraction in this study. However, dissolved organic matter (DOM) is also important, especially since high DOM concentration in Funka Bay (during the spring phytoplankton bloom and in the summer according to Yoshida et al. 1984) coincided with the high bacterial growth rates in this study.

Bacterial abundance was relatively stable throughout the year $(\mathrm{CV}=20 \%)$. This relative variability was low compared to that of both chl a $(\mathrm{CV}=130 \%)$, and HNF $(\mathrm{CV}=100 \%)$. Bacterial abundance was stable, even though the CV for bacterial production was high $(\mathrm{CV}=100 \%)$. This suggests that grazing (top-down) is an important control mechanism in Funka Bay. One of the major bacterial predators is the HNF. In this study, the HNF seemed to be directly cropping bacterial production, as there were significant correlations between bacterial production and HNF abundance for both the early $(\mathrm{r}=0.42, \mathrm{n}=20, \mathrm{p}<0.05)$, and late $(\mathrm{r}=0.45, \mathrm{n}=$ $28, \mathrm{p}<0.01$ ) periods (Fig. 7A). Higher bacterial production from February until May supported higher HNF abundance, which regulated the bacterial abundance through grazing. Although lower bacterial production in the late period (June until December) supported lower HNF abundance, decreasing HNF abundance throughout the water column from summer to winter could also be attributable to grazing activities by micro- and net-zooplankton. Odate (1992) reported that the food requirements of these potential HNF predators are highest during this period.

Temperature has also been reported to be important, in affecting the bacterial growth rate, e.g., in Chesapeake Bay (Shiah \& Ducklow 1994). In this study, bacterial growth rate $\left(\log \mathrm{h}^{-1}\right)$ correlated with temperature $\left({ }^{\circ} \mathrm{C}\right)$ only in the period from June until December (Fig. 7B: $r=0.51, n=30, p<0.01$ ). As seawater temperatures increased in summer, bacterial growth rate increased nearly 3 -fold for every $10^{\circ} \mathrm{C}$ rise in temperature $\left(Q_{10}=3.0\right)$. From February until May, changes in bacterial growth rates were independent of tempera- 
ture (Fig. 7B: $\mathrm{r}=0.11, \mathrm{n}=21, \mathrm{p}>0.25$ ). In this period, the spring phytoplankton bloom occurred, and the changes in bacterial growth rates were probably connected with nutrients from the phytoplankton bloom. This is in agreement with the suggestion by Felip et al. (1996) that temperature has little effect on bacterial growth in resource-rich environments.

In this study, annual bacterial production was estimated at $140 \mathrm{~g} \mathrm{C} \mathrm{m}^{-2} \mathrm{yr}^{-1}$; this is high in relation to the annual primary production for Funka Bay $\left(100 \mathrm{~g} \mathrm{C} \mathrm{m}^{-2}\right.$ $\mathrm{yr}^{-1}$ for 1974 and 1975: Yanada \& Maita 1978; $140 \mathrm{~g} \mathrm{C}$ $\mathrm{m}^{-2} \mathrm{yr}^{-1}$ for 1984 and 1985: Odate 1992; $170 \mathrm{~g} \mathrm{C} \mathrm{m}^{-2}$ $\mathrm{yr}^{-1}$ for 1999 and 2000: Kudo unpubl. data). This is higher than the annual mean ratio of bacterial to primary production of $20 \%$ for aquatic systems suggested by Ducklow (1999). To account for the bacterial respiration loss, we calculated bacterial carbon demand (BCD) according to the following equation: $\mathrm{BCD}=$ $\mathrm{BP} / \mathrm{BGE}$, where BGE is the bacterial growth efficiency. Assuming a BGE of $30 \%$ (del Giorgio \& Cole 2000), the
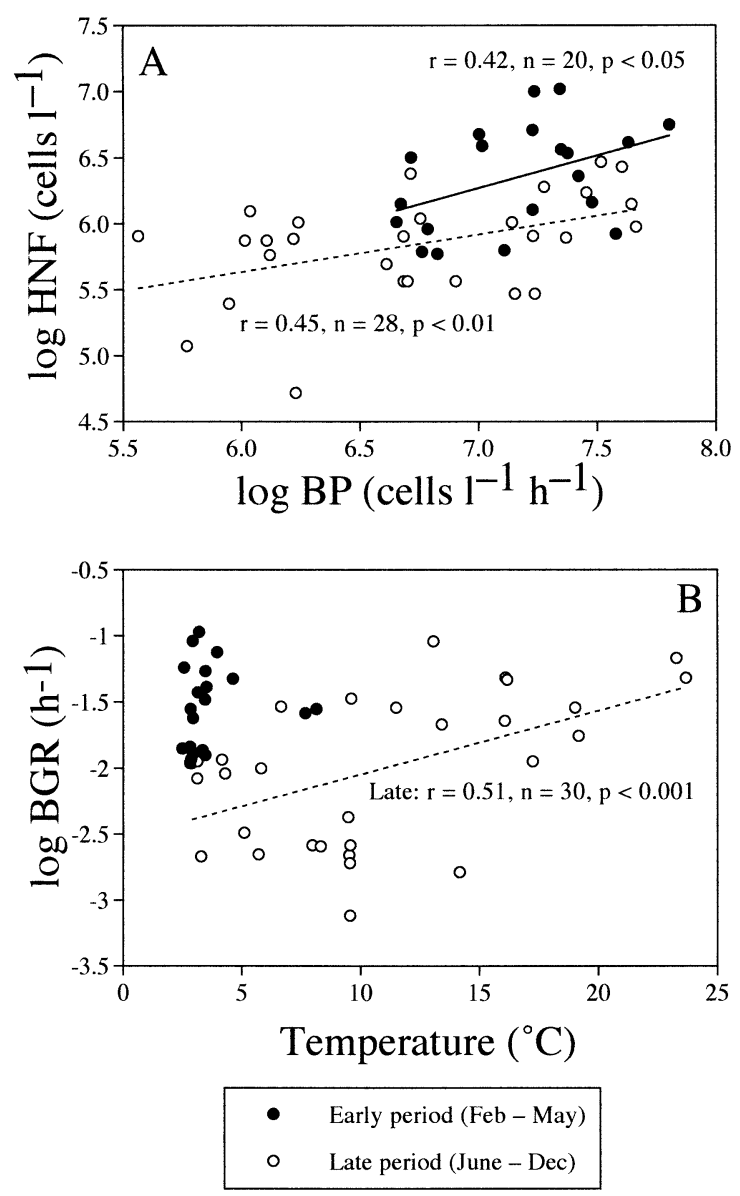

Fig. 7. Correlation analyses for both early and late periods for (A) $\log$ bacterial production (BP) and log heterotrophic nanoflagellate abundance (HNF), and (B) log bacterial growth rate (BGR) and seawater temperature annual BCD would be $470 \mathrm{~g} \mathrm{C} \mathrm{m}^{-2} \mathrm{yr}^{-1}$, higher than annual primary production. This was true even after taking into account that $50 \%$ of primary production is released as DOM (Nagata 2000), giving a gross annual primary production of $340 \mathrm{~g} \mathrm{C} \mathrm{m}^{-2} \mathrm{yr}^{-1}$. Periods in which bacterial carbon demand was more than phytoplankton production have been previously reported for both estuarine and coastal ecosystems (Goosen et al. 1997, Amon \& Benner 1998). Given the constraint that the amount of carbon available to bacteria from primary production was insufficient to balance the measured demand in this study, an additional source probably existed.

Possible sources of organic matter include terrigenous DOM (riverine input) (Opsahl \& Benner 1997), and DOM from periods during which primary production is high relative to bacterial production ('uncoupling') (del Giorgio et al. 1997). Inflow of Tsugaru warm water into Funka Bay was first hypothesized by Yanada \& Maita (1978) to bring in additional organic matter. As salinity increases during this period could be attributed to the inflow of Tsugaru warm water, correlation analyses were carried out between POC, phytoplankton biomass and salinity (Fig. 8). To avoid particulate organic matter from primary production in the euphotic layer from affecting the analyses, data for

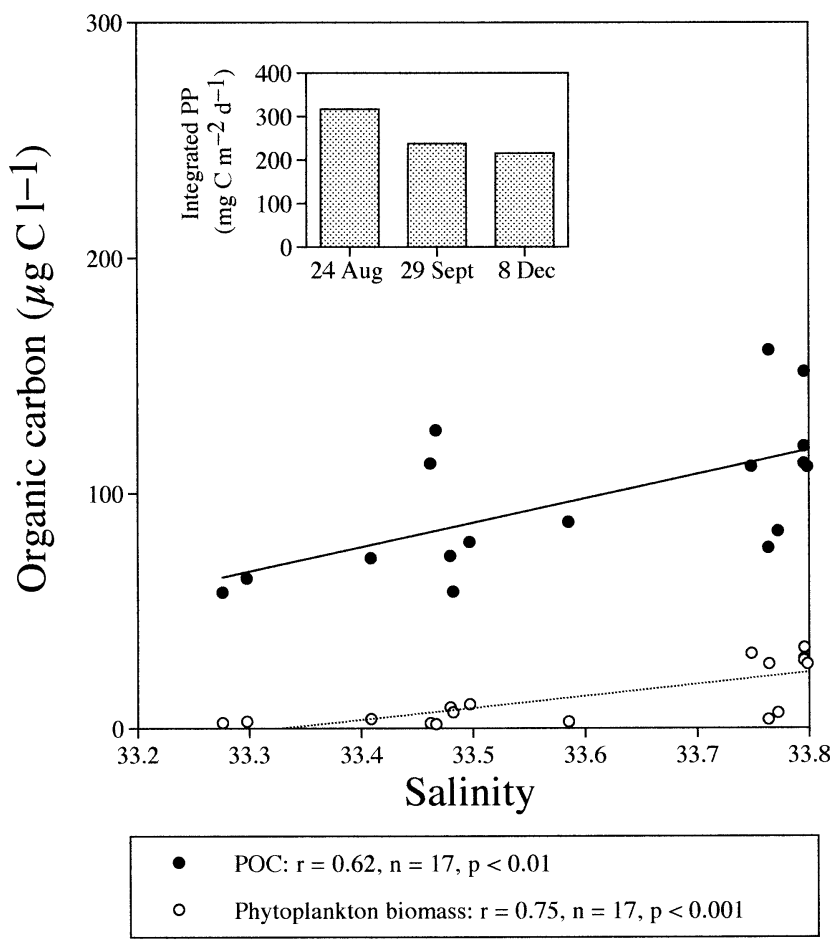

Fig. 8. Relationship between particulate organic carbon (POC) and salinity and between phytoplankton biomass and salinity. Data set from the 30 to 90 m layer from August until December. Inset: integrated primary production (PP) observed during same period (Kudo unpubl. data) 
the correlation analyses were taken from below the euphotic layer from August until December. The results show that both POC and phytoplankton biomass correlated with salinity $(\mathrm{r}=0.62, \mathrm{p}<0.01, \mathrm{n}=17$ and $\mathrm{r}=0.75, \mathrm{p}<0.001, \mathrm{n}=17$, respectively). This source of organic matter (POC and phytoplankton biomass) could not be attributed to the primary production in the euphotic layer, as integrated primary production during this period did not increase (Kudo unpubl. data) (see inset in Fig. 8). In view of this, the inflow of Tsugaru warm water must have brought additional organic matter into Funka Bay. However, POC concentration differed between September and December samplings by about an average of $40 \mu \mathrm{g} \mathrm{Cl}^{-1}$ (or only $4 \mathrm{~g} \mathrm{C} \mathrm{m}^{-2}$ in a $100 \mathrm{~m}$ water column). This is small compared to the estimated deficit of $130 \mathrm{~g} \mathrm{C} \mathrm{m}^{-2} \mathrm{yr}^{-1}$, and probably insignificant, as the Tsugaru warm water inflow also coincided with the winter season when bacterial production was low.

Acknowledgements. We are grateful to Takeshi Yoshimura, Taichi Yokokawa, the Captain and crew of the RV 'Ushio Maru', Faculty of Fisheries, Hokkaido University, for their assistance during sampling. We are also grateful to the Ministry of Education, Japan, for providing financial assistance to C.W.L.

\section{LITERATURE CITED}

Amon RMW, Benner R (1998) Seasonal patterns of bacterial abundance and production in the Mississippi River plume and their importance for the fate of enhanced primary production. Microb Ecol 35:289-300

Baines S, Pace M (1991) The production of dissolved organic matter by phytoplankton and its importance to bacteria: patterns across marine and freshwater systems. Limnol Oceanogr 36:1078-1090

Bloem J, Bär-Gilissen MJB, Cappenberg TE (1986) Fixation, counting, and manipulation of heterotrophic nanoflagellates. Appl Environ Microbiol 52:1266-1272

Caron DA, Dam HG, Kremer P, Lessard EJ, Madin LP, Malone TC, Napp QJM, Peele ER, Roman MR, Youngbluth MJ (1995) The contribution of microorganisms to particulate carbon and nitrogen in surface waters of the Sargasso Sea near Bermuda. Deep-Sea Res 42:943-972

Cole JJ, Findlay S, Pace ML (1988) Bacterial production in fresh and saltwater ecosystem: a cross-system overview. Mar Ecol Prog Ser 43:1-10

Day RA Jr, Underwood AL (1980) Quantitative analysis, 4th edn. Prentice-Hall, Englewood Cliffs, NJ

del Giorgio PA, Cole JJ (2000) Bacterial energetics and growth efficiency. In: Kirchman D (ed) Microbial ecology of the oceans. Wiley, New York, p 289-325

del Giorgio PA, Cole JJ, Cimbleris A (1997) Respiration rates in bacteria exceed phytoplankton production in unproductive aquatic systems. Nature 385:148-151

Ducklow HW (1999) The bacterial component of the oceanic euphotic zone. FEMS Microbiol Ecol 30:1-10

Ducklow HW, Carlson CA (1992) Oceanic bacterial production. Adv Microb Ecol 12:113-181

Felip M, Pace ML, Cole JJ (1996) Regulation of planktonic bacterial growth rates: the effects of temperature and resources. Microb Ecol 31:15-28

Ferrier-Pagès C, Gattuso JP (1998) Biomass, production and grazing rates of pico- and nanoplankton in coral reef waters (Miyako Island, Japan). Microb Ecol 35:46-57

Fuhrman JA, Azam F (1982) Thymidine incorporation as a measure of heterotrophic bacterioplankton production in marine surface waters: evaluation and field results. Mar Biol 66:109-120

Fuhrman JA, Noble RT (1995) Viruses and protists cause similar bacterial mortality in coastal seawater. Limnol Oceanogr 40:1236-1242

Fukami K, Murata N, Morio Y, Nishijima T (1996) Distribution of heterotrophic nanoflagellates and their importance as the bacterial consumer in a eutrophic coastal seawater. J Oceanogr 52:399-407

Goosen NK, Rijswijk PV, Bie MD, Peene J, Kromkamp J (1997) Bacterioplankton abundance and production and nanozooplankton abundance in Kenyan coastal waters (Western Indian Ocean). Deep-Sea Res 44:1235-1250

Hoppe HG (1991) Microbial extracellular enzyme activity: a new key parameter in aquatic ecology. In: Chróst RJ (ed) Microbial enzymes in aquatic environments. SpringerVerlag, New York, p 60-122

Kefford B, Kjelleberg S, Marshall KC (1982) Bacterial scavenging: utilization of fatty acids localized at the solid/ liquid interface. Arch Microbiol 133:257-260

Kepner RL Jr, Pratt JR (1994) Use of fluorochromes for direct enumeration of total bacteria in environmental samples: past and present. Microbiol Rev 58:603-615

Kirchman DL, Mitchell R (1982) Contribution of particlebound bacteria to total microheterotrophic activity in five ponds and two marshes. Appl Environ Microbiol 43: 200-209

Kudo I, Matsunaga K (1999) Environmental factors affecting the occurrence and production of the spring phytoplankton bloom in Funka Bay, Japan. J Oceanogr 55:505-513

McManus GB (1993) Growth rates of natural populations of heterotrophic nanoplankton. In: Kemp PF, Sherr BF, Sherr EB, Cole JJ (eds), Handbook of methods in aquatic microbial ecology. Lewis Publishers, Inc, Boca Raton, FL, p 557-562

Naganuma T (1997) Abundance and production of bacterioplankton along a transect of Ise Bay, Japan. J Oceanogr 53:579-583

Naganuma T, Miura S (1997) Abundance, production and viability of bacterioplankton in the Seto Inland Sea, Japan. J Oceanogr 53:435-442

Nagata T (2000) Production mechanisms of dissolved organic matter. In: Kirchman DL (ed) Microbial ecology of the oceans. Wiley, New York, p 121-152

Odate T (1992) Production ecology within the lower trophic levels in marine ecosystems. Mem Fac Fish Hokkaido Univ 39:1-82

Ohtani K (1971) Studies on the change of the hydrographic conditions in the Funka Bay. II. Characteristics of the waters occupying the Funka Bay. Bull Fac Fish Hokkaido Univ 22:58-66 (in Japanese with English abstract)

Opsahl S, Benner R (1997) Distribution and cycling of terrigenous dissolved organic matter in the ocean. Nature 386 : $480-484$

Sherr EB, Sherr BF (1984) Role of heterotrophic protozoa in carbon and energy flow in aquatic ecosystems. In: Klug MJ, Reddy CA (eds) Current perspectives in microbial ecology. American Society for Microbiology, Washington, DC, p 412-423

Shiah FK, Ducklow HW (1994) Temperature regulation of het- 
erotrophic bacterioplankton abundance, production, and specific growth rate in Chesapeake Bay. Limnol Oceanogr 39:1243-1258

Simon M, Welschmeyer NA, Kirchman DL (1992) Bacterial production and the sinking flux of particulate organic matter in the subarctic Pacific. Deep-Sea Res 39:1997-2008

Suzuki R, Ishimaru T (1990) An improved method for the determination of phytoplankton chlorophyll using $\mathrm{N}, \mathrm{N}$ dimethylformamide. J Oceanogr 46:190-194

Weisse T, Scheffel-Möser U (1991) Uncoupling the microbial loop: growth and grazing loss rates of bacteria and hetero-

Editorial responsibility: Fereidoun Rassoulzadegan, Villefranche-sur-Mer, France trophic nanoflagellates in the North Atlantic. Mar Ecol Prog Ser 71:195-205

Yanada M, Maita Y (1978) Production and decomposition of particulate organic matter in Funka Bay, Japan. Estuar Coast Mar Sci 6:523-533

Yoshida H, Maita Y, Shiomoto A (1984) Seasonal variation of dissolved organic matter in Funka Bay. Bull Fac Fish Hokkaido Univ 35:254-270 (in Japanese with English abstract)

Zar JH (1996) Biostatistical analysis, 3rd edn. Prentice-Hall, Englewood Cliffs, NJ

Submitted: October 9, 2000; Accepted: December 30, 2000 Proofs received from author(s): February 24, 2001 